\title{
GEOGRAPHICAL ANALYSIS OF SUMMER HOUSES BY THE LAKE HAZAR IN TERMS OF THEIR LOCATION OF CONSTRUCTION (PROVINCE OF ELAZIĞ-TURKEY)
}

\author{
Ayșe ÇAĞLIYAN* \\ Firat University, Faculty of Humanities and Social Sciences, Department \\ of Geography, University Mah, 23200, Elazig, Turkey, e-mail: acaglayan@firat.edu.tr \\ Gülsen AYHAN \\ Frrat University, Graduate School of Social Sciences, Department \\ of Geography, University Mah. 23200, Elazig, Turkey, e-mail: gulsen.4401@gmail.com
}

\begin{abstract}
Citation: Çağliyan, A., \& Ayhan, G. (2019). GEOGRAPHICAL ANALYSIS OF SUMMER HOUSES BY THE LAKE HAZAR IN TERMS OF THEIR LOCATION OF CONSTRUCTION (PROVINCE OF ELAZIĞ-TURKEY). GeoJournal of Tourism and Geosites, 25(2), 648-663. https://doi.org/10.30892/gtg.25229-387
\end{abstract}

\begin{abstract}
The factors related to the location of the second houses are commonly related to geography and tourism geography. The second houses diversify according to time and place in terms of their location of construction and the distribution of these houses varies according to the physical and human geography elements. The discipline of geography has an important place in the identification of these elements and in the analysis of the location of the second houses. The aim of our study is to evaluate the summer houses situated in and around Lake Hazar in terms of their location and analyze their suitability in the sense of sustainability. Suitability of the summer houses were obtained with the help of Geographic Information Systems, the maps by using the "Multi-Criteria Decision Making" method and land use suitability classes by using "weighted overlay" and summer houses were classified as not suitable, moderately suitable and suitable. According to the suitability map and the field studies, since it lacked faulted steep slopes, the excess of the alluvial cone, and the presence of wide shores and beaches, the northern shores of the lake was more suitable for settlement and construction of the southern coast in comparison to the southern coats. These suitable locations were the Güney Village of the town of Sivrice, and Cevizdere and Gölardı Villages of the Central district. Some of the holiday sites-houses in the north of the lake were built along the stream and within the stream. Even though these areas were dry streams, they suffered from floods in the past and therefore, are not suitable for settlement.
\end{abstract}

Keywords: Elazig, Turkey, Lake Hazar, Tourism, Secondary Homes, Suitability Analysis

\footnotetext{
* Corresponding author
} 


\section{INTRODUCTION}

People who escaped from the uncertainties and threats of the natural environment initially built the cities. The people who have built the cities now prefer to go back to nature by escaping from the crowds of the cities, the busy work tempo, heaps of gigantic buildings and all the processes brought about by the phenomenon of urbanization. The rapid destruction of the cities and the surrounding natural areas and the rapid growth of the artificial environment with industrialization revitalized the theme of a natural return in the human mind. In order to meet this requirement, the human longing for the unspoiled natural environment has returned to nature in certain periods and days of the year. At the same time, the population congested with the industrial revolution and the existence of a stressful life brought about by this population rise have also increased the needs of people to relax. Consequently, the people who are tired of this environment, seeking a more tranquil environment have begun to build second homes in an area close to where they have lived. The second homes are very attractive for people who want a holiday that is close to their own habitat and spend more reasonable prices for it.

The mobility encouraged by the tourism activities, rigorous construction on the coasts which are the most important attractive element of tourism, exceeding the transport capacity in different touristic destinations and the deterioration in the natural and cultural environment as a result of intensive demand increased the importance of geographical research in tourism (Richards, 2017: 169). While the recent increase in the tendency to own second homes has gained importance in the research of these regions, it is equally necessary, at the same time, to investigate where these houses are constructed on the site and the necessity of investigating these places has emerged.

The concept of second home is defined in different ways and the functions of the second homes are diversified according to the location. The second homes, defined as a kind of private property investment utilized during the holiday times and sited outside the urban living areas, are situated in areas that have high recreational qualities such as sea, lake, stream edges, plateau and mountain but need to be protected in terms of ecosystem. Since these houses are temporarily used in a different way from the houses that are utilized permanently and have priority of use, and left empty for most of the year, they are called as "second homes". With the concept "second" in the housings mentioned by the terms such as holiday homes, weekend houses, cottages, country house, summer house and chalet, it is not which housing, but the function that is granted in use is explicated (Arkon, 1997: 40-42). The concept of second home can be defined as fixed structures which are used in delimited time periods for people to rest and have fun, which are purchased or rented in places preferred due to their natural and human attractiveness, and which affect the natural environment, economy and social life of their geographical location (Küçük, 2016: 6). The recent increase in the intensity of the second housing has augmented the importance of researches.

Even though the second housing tourism is an important notion of tourism, it has attracted only limited academic interest (Müller 2004: 387). However, the rapid recent increase in the number of second homes worldwide has revealed the tendency of many disciplines to explore this area; the concept of second housing has become important in the researches of tourism professionals, city and regional planners, architects, economists, business managers and legal experts. While a significant part of the researches conducted in the world are conducted on the basis of "second homes and tourism" 2008 (Hall \& Müller, 2004; Marjavaara, 2008; Roca, 2013; Adamiak et al., 2015), another part of them deals with "the effects of second homes" (Hiltunen, 2007; Hoogendoorn \& Visser, 2010; Rye, 2011; Roca et al., 2011; Long \& Hoogendoorn, 2013). 
Even though the locations where the second homes are built deliver economic benefits, some negative consequences may arise. The second homes, along with the developments in tourism, provide various economic benefits. However, even though the second home owners bring a new source to the community, it is suggested that the second home population can lead to economic, social and cultural conflicts and controversies in the local communities (Rye, 2011: 263). Second housing, parallel to industrialization and urbanization movements, emerged as a result of factors such as the increase in economic opportunities, the development of transportation, augmented leisure time and the effect of fashion (Özgüç, 1977). In our country, as in the world, the number of second homes increased in recent years, this increase was observed not only on the sea coasts but on the lake coasts as well. Those seeking a peaceful place to have fun and relax built second homes by taking advantage of the lake coasts. In the developed and developing countries, the number and location of the second homes, which are built by the high-income segment of the society in the rural areas and situated mostly in closerange, and utilized for leisure time in short-term period have been increasing.

Their owners use these houses for small-scale activities such as going for swimming in the sea-lake, fishing and the like. These expensive houses have become a huge industry in economically developed countries where many people can participate in different activities. In the province of Elazığ, both around Lake Hazar and the village settlements corresponding to the vineyard garden areas, and around main road are the spaces where summer houses are increasingly seen more and more.

The summer houses around the province of Elaziğ are traditionally the second houses with vineyards and gardens, and these houses are still widely used today and still being built. The second houses with vineyard and garden around Kuzova, Uluova, Harput and Lake Hazar, that is the summer houses are quite common. Apart from the summer houses with traditional vineyards and gardens, the second houses, which are used for holiday in summers, have started to be built around Lake Hazar after 1980. The summer houses on the coasts of Lake Hazar were mostly built in the form of housing estates.

In the Eastern Anatolia region, which is closed to the ocean effect and consists of high mountainous areas and where there is very little forest vegetation, the coasts of rivers and lakes are of great importance as recreation areas. The coasts of Lake Hazar have a special characteristic among such places. The lake coasts not far from the provincial centers (22 km away from Elazı̆ Malatya), where there is a large population (Elazığ, Diyarbakır and Malatya), has become an important recreation area of these three cities with its natural beauty as well as the ease of transportation (Yiğit, 1994: 163). The fact that coasts of the Lake Hazar were cooler than the city center during the summer months, the forest areas that were formed as a result of the forestation efforts allowed the summer houses to be built on the coast of the lake because of the many tourism potentials. After the 1980s in Turkey, it is observed that the demand for second homes began to increase rapidly. According to the digital data prepared by the General Directorate of Population and Citizenship Affairs, as of 2008, there have been 546 thousand 454 summer-seasonal homes in Turkey.

Number of Second Homes by Regions Second in Turkey

1- Black Sea Region 169 282, 2- Marmara 110 495, 3- Aegean 87 106, 4Mediterranean 79 480, 5- Central Anatolia 71 708, 6- East Anatolia 22 643, 7- Southeast Anatolia 5740 (Kozak \& Duman 2011: 230).

While ignoring the natural environment characteristics of the locality causes some problems today, it is not a coincidence that a significant portion of the second houses are collected on the coasts, and that they are spread in strongly attractive places 
such as mountains, highlands, rivers, lakes and forests. These houses appear as points that require analysis of spatial characteristics. Therefore, the second houses are related to the geography of settlement, economic geography, cultural geography, tourism geography as well as the physical geography in terms of land allocation and natural environment characteristics that affect the selection of the construction location and governs the price policy. This not only indicates the necessity of examining the geographical environment characteristics, but also explicated the reason for the misuse and out of purpose use of the land (Emekli, 2014: 29). The discipline of geography is a leading contributor to tourism research. Although tourism geography research covers a broad spectrum of issues and approaches the most distinctive approach that geography brings to tourism scholarship is through adopting a spatial view (Rogerson, 2018: 835).

As a result of the changes in the welfare level and in the social structure in the world, especially in the last 30-40 years as in the system of timesharing, the issue of second homes has started to make its mark. In term of meeting the recreation needs of those who are currently employed and have the economic power, on the one hand, and the elderly groups that have earned the right to retire and have plenty of leisure time despite economically not powerful, on the other hand, the second homes have been cast a significant role to play (Kozak \& Teoman, 2011: 228). In the Second Housing Symposium held in London in 1974, it was emphasized that the location of the second houses in Europe and North America was based on three important choices:

$>$ The rural areas that can provide easy access to large urban centers,

$>$ Coasts and immediate vicinity,

> High areas with attractive and great view (Emekli, 2014: 26).

The purpose of our study is to evaluate the summer houses located in and around the Lake Hazar in terms of their location and analyze their adequacy in terms of sustainability. Therefore, taking into consideration the geographic factors, determining the location of summer houses and making plans constitute the main objectives of our study. Geographic planning is obtained not by a single geographic criterion but by taking into consideration multiple geographic criteria and making separate evaluation. Either the misuse of the land resulting from the relationship between the natural environment and the human environment, or the desire to live in a well-ordered environment makes planning a necessity. Planning land use signifies planning the future of people (Dağlı \& Çağllyan 2016: 84). The geographers have an important role in the planning process by applying the geographical criteria. Therefore, in our study, the adequacy of the houses built in and around the Lake Hazar with the help of GBS was analyzed by using the multi criteria decision making method. In this manner, identifying the adequacy of the houses existing in the study area will guide the summer (second) homes to be built.

\section{STUDY AREAS}

In the Upper Euphrates Section of the Eastern Anatolia Region, the Lake Hazar, which is located within the boundaries of the province of Elazıg in the Southeastern Taurus section, is $22 \mathrm{~km}$ away from Elazığ and $100 \mathrm{~km}$ away from Diyarbakır. The Lake Hazar, which occupies the base of a sediment trench extending in the direction of the SW-NE, has a length of $20 \mathrm{~km}$ and a width ranging from 3-5 km. Even though the lake area varies depending on the changes of level, today it has altitude of $1240 \mathrm{~m}$. and covers an area of approximately $80 \mathrm{~km}^{2}$ (Yiğit, 1994: 289). Lake Hazar, which has the characteristics of a natural park, occupies the base of a depression trench located between the masses of the Çelemlik-Mastar mountain rage in the south and the masses of the Hazarbaba-Yaylım Mountains in the north. These mountains descending into the 
lake with steep slopes, do not allow the formation of extensive level area around the lake. The main level areas of the lake are composed of the Kürk (Fur) delta formed in the Kürk (Fur)-water mouth in the west and of the Gezin delta formed in the mouth of the Zıkkım stream in the east (Figure 1). Even though the touristic facilities could not be established due to the marshy soil on the Kürk (Fur) delta, the Gezin delta is one of the most densely populated areas. Apart from these deltas, the alluvial cones and fans formed by the small streams on the lake coast descending along the steep slopes of the mountains and bringing the water of a fault source to the lake constitute the main areas to be able to establish the facilities. In fact, most of the facilities located on the north and south coast of the lake were established in such places (Yiğit, 1994: 289).

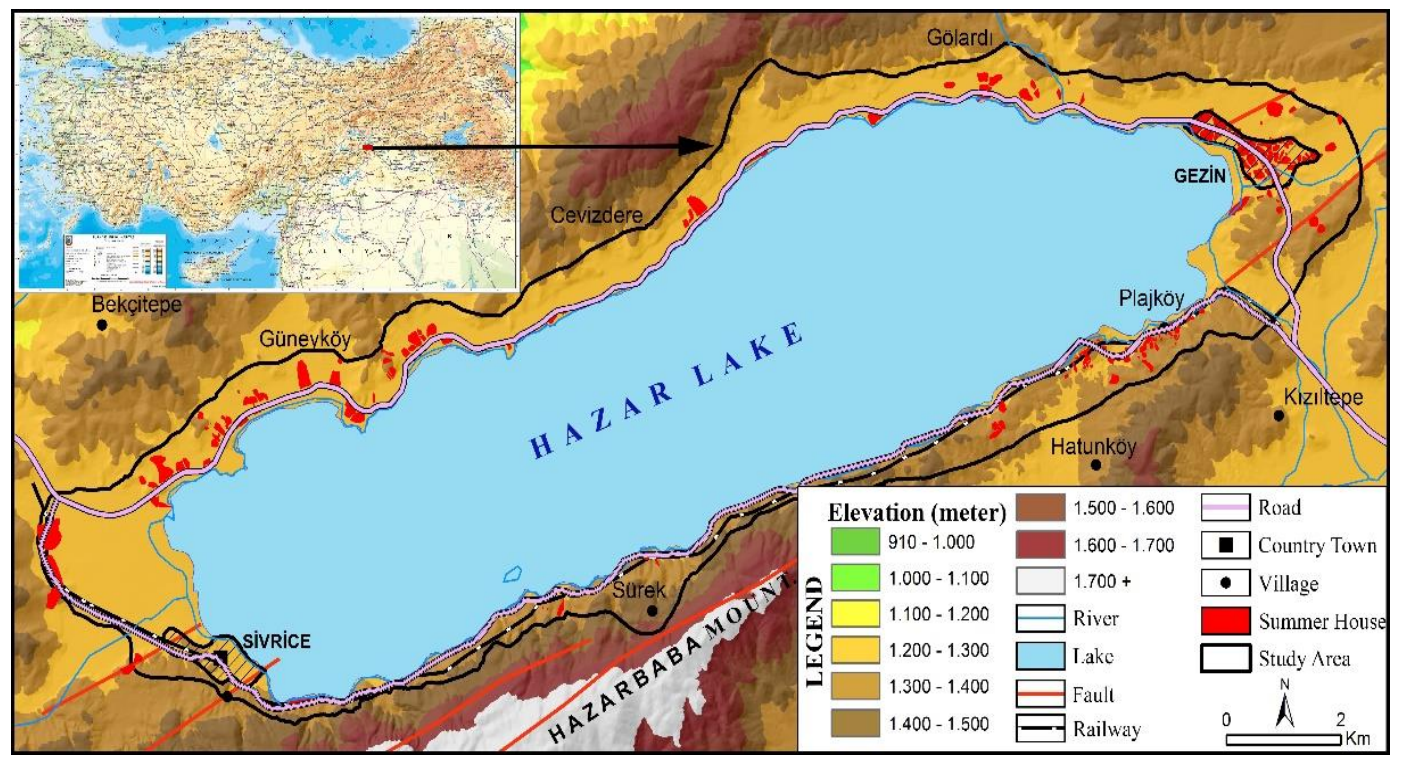

Figure 1. Location and Physical Map of Lake Hazar

The Caspian Lake trench corresponds to the Eastern Anatolian Fault Zone (EAF) and possesses a basin characteristic of "Pull-Apart" type. The depth of the lake is high due to this basin development model. The southern coast of the lake (Hazarbaba mountain slopes) is steeper than the north coast due to the EAF; therefore, the beach areas are very narrow and limited. This situation has also affected the transportation system. There are the Elazığ-Diyarbakır railway which is narrow on the south coast and a narrow highway which is not used much and the main highway connecting Elazığ to the SE Anatolia Region on the stretched north coast (Figure 1-2).

\section{STUDY DATA AND METHOD}

Currently, landscape-ecological analysis is considered one of the most important methods in the study of the natural capacity of a territory, which takes into account structural and functional dynamic features of natural complexes of different taxonomic ranks (Kabiyev et al., 2019: 645). In the study, maps were obtained from the basic data derived from the Provincial Land Assets (1997), Topography Maps (25.000) and Corine Land Use (2006) and Mineral Research Exploration (MRE). Numerical elevation model (NEM) was created by the digitization of topography maps and maps were generated 
with this data for slope, geomorphology, aspect and elevation criteria. A general land use map was created from the Corine data and field observations. Soil and land use capability maps were obtained by Elazığ Provincial Land Assets (1997) data.

The geological map (100.000) was generated with the data obtained from the MRE. The base data obtained related to the study area was mapped in the ArcGIS program with the geographic information systems. The "Multi-criteria decision-making method (M-DMM)" was used in order to determine the location adequacy of the summer houses. The geographical information systems based multi-criteria decisionmaking analysis was performed using the ArcGIS 10.3.1 programs. The resulting maps were brought to the same pixel size and converted to a grid format.

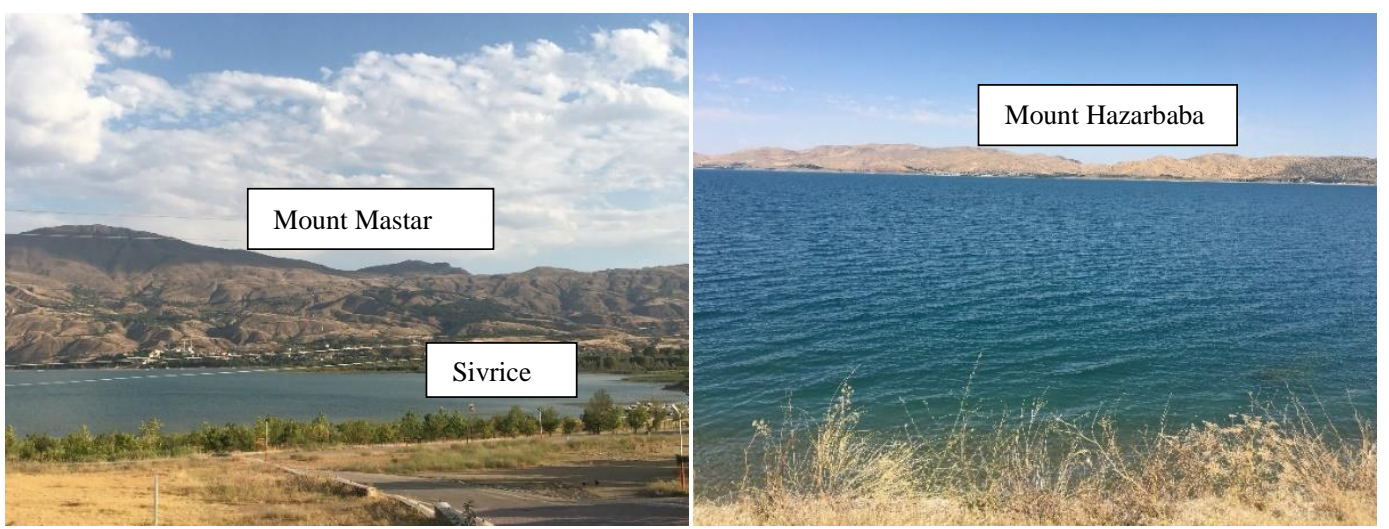

Figure 2. View of the South and North Coast of Lake Hazar

The converted maps were subjected to the "Weighted Overlay" analysis in order to obtain land use adequacy classifications and the summer houses were classified as not adequate, slightly adequate, moderately adequate and adequate. In order to obtain the information on the location of the houses where they were built, interviews were made with the authorized persons during the field study, and photographs were taken regarding the study area and the subject. Especially in order to assist with the analysis, problems and solutions in these areas were discussed and synthesized. Consequently, decisions were taken on the most adequate possible locations for the summer houses. Correspondingly, it was discussed whether the previously constructed housing estates or the individually built second houses were built in most adequate location.

\section{RESULTS DISCUSSIONS}

The factors affecting the location of the second houses and the characteristics affecting the usage time and duration are related with geography and tourism geography. Geography plays a key role in the analysis of the second housing-tourismenvironment relations. Analyzing the relations of geography and tourism geography in the studies related to the second housing provides data for other disciplines. Second homes in Turkey vary by time and location, and the economic, social, political and technological reasons affect the distribution, usage patterns architectural characteristics of these houses. The discipline of geography has an explanatory function in revealing these relations (Emekli, 2014: 27). Therefore, the discipline of geography has an important role in making location selection analysis of the second homes. Geographical elements have an important role to play in the construction of summer houses. 

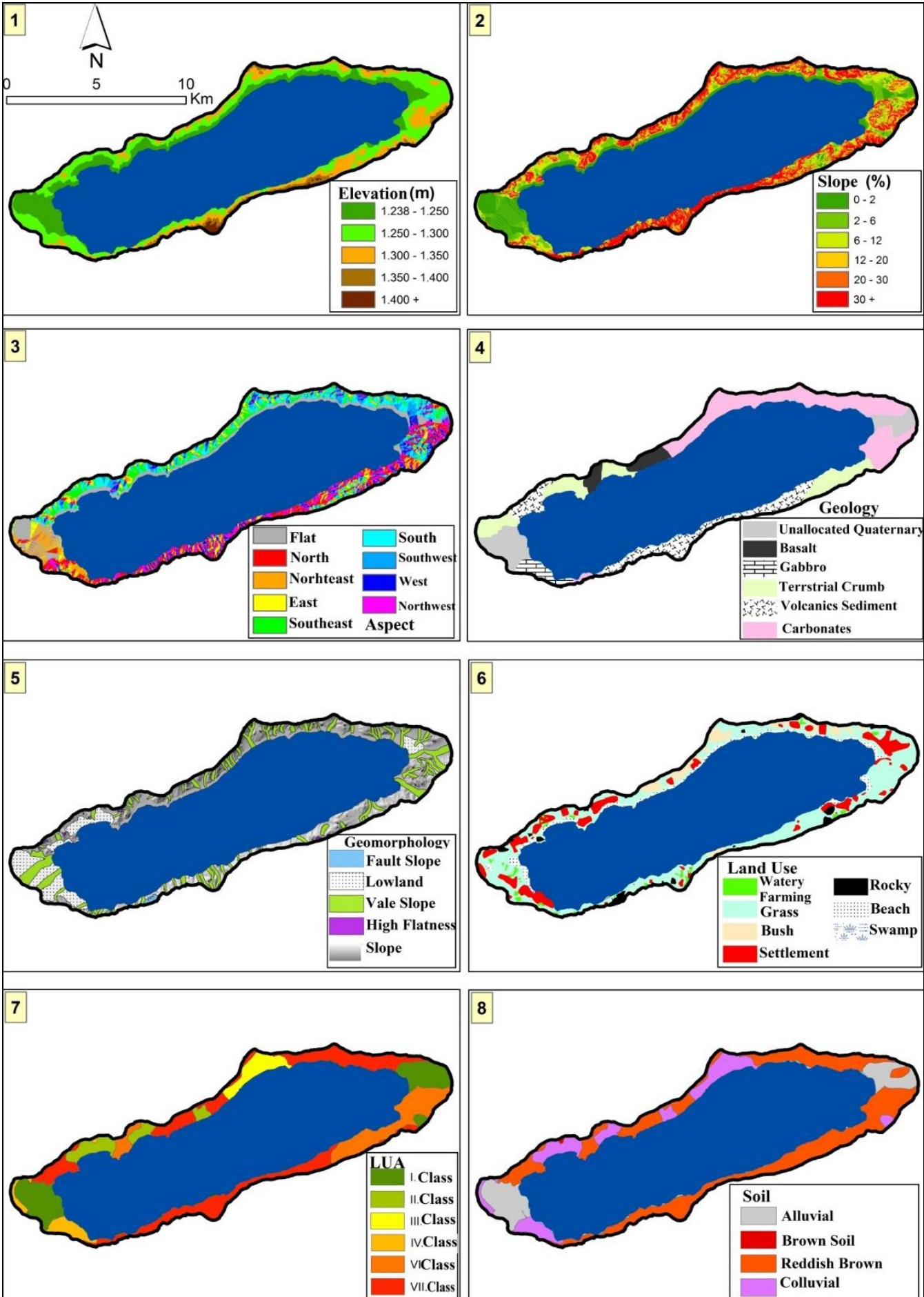

Figure 3. Criteria used in the analysis; 1) Elevation 2) Slope

3) Aspect 4) Geology 5) Geomorphology 6) Land Use 7) Land Use Capability 8) Soil 
The adequacy of the land can be determined using the geographic elements. In the present study, eight criteria were determined in order to make geographic analysis of the summer house locations around Lake Hazar. These criteria were elevation, slope, aspect, geology, geomorphology, land use, land use capability and soil (Figure 3). By combining these criteria, we tried to reveal the locations which were adequate and not adequate for the selection of summer houses around Lake Hazar.

In the resulting map, the degree of adequacy was divided into four classes and presented as "adequate", "less adequate", "moderately adequate" and "adequate places" (Figure 4). The present distribution of summer houses around Lake Hazar is concentrated in two areas: The first is the northern coasts of the lake and the second is the east and SE coasts of the lake. These areas administratively correspond to the villages of the Central, Sivrice and Maden districts. Summer houses were concentrated in the Güney village of the Sivrice district, Cevizdere and Gölardı villages of the Central district and Gezin and Plajköy villages of the Maden district (Figure 4).

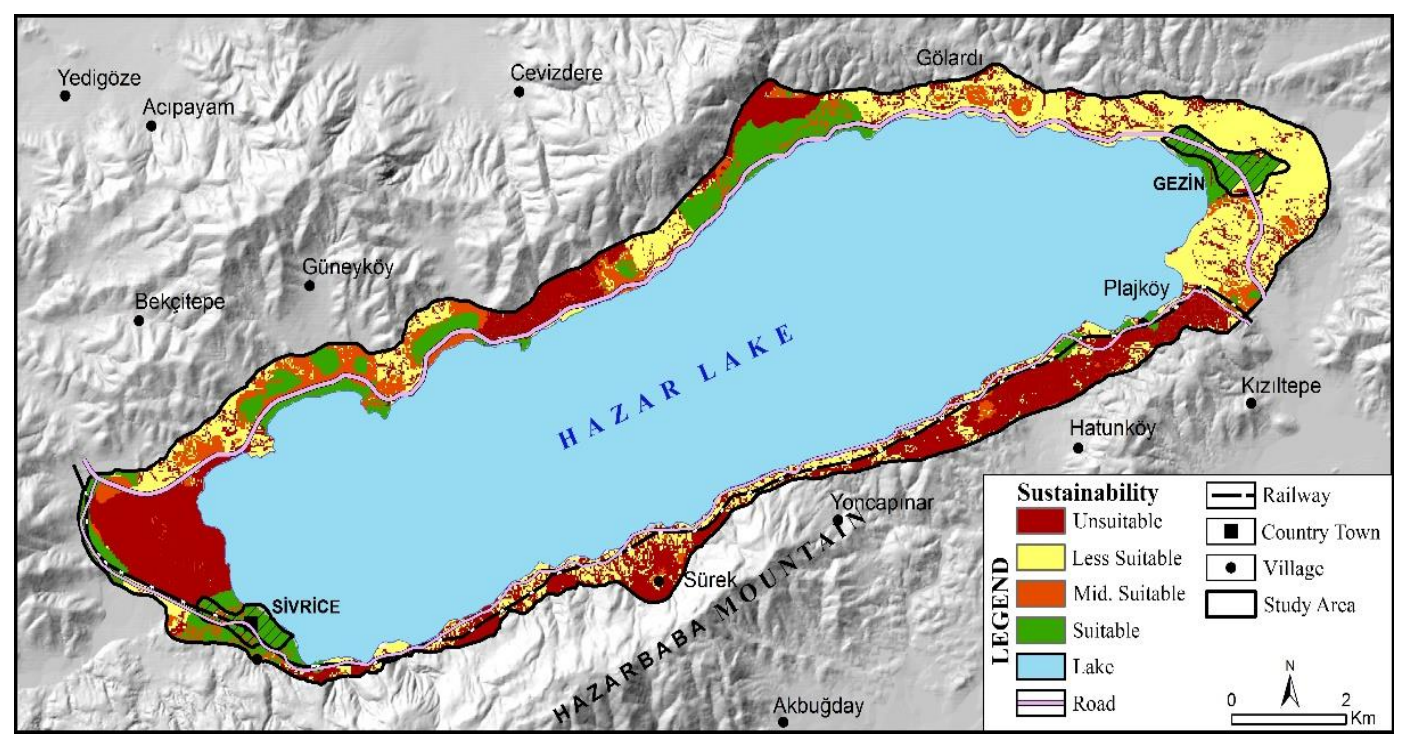

Figure 4. Land Adequacy Map of the Summer Houses in and around Lake Hazar

\section{Güney Village Summer House Location}

Güney village is a village settlement on the Elazığ-Diyarbakır highway in the north of the Lake Hazar, affiliated with the town of Sivrice. Güney village is the densest residential area for summer housing in our study area. The main village settlem ent was established within the valley on the southern skirts of the Çelemlik Mountains. However, the village, over time, began to move from its main center towards the coasts of the Lake Hazar (Dervişali mountain house). Summer houses were first established with the Beyaz Evler (White Houses) housing estate in this village (1984).

Only the Beyaz Evler and the Turquoise housing estates were located between the highway and the lake. Other housing estates were located on the north of the highway, not on the lake coast; that is, outside the housing estate area and in areas without planning permission. Nevertheless, it was the beginning of the $1990 \mathrm{~s}$ that the construction of the housing estates or single houses started to develop rapidly. There are a total of 632 summer houses in this area, consisting of 27 holiday estates and 
individual houses concentrated in 4 different areas (Figure 4). This area is still under construction in terms of summer houses. These houses are almost very intermittently, sometimes adjacently distributed, from the western edge of the Lake Hazar to the SHW (State Hydraulic Works) Training Facilities (Figure 5). While the winter population of the village is 162 persons (2017), it is around 10 ooo in summer.

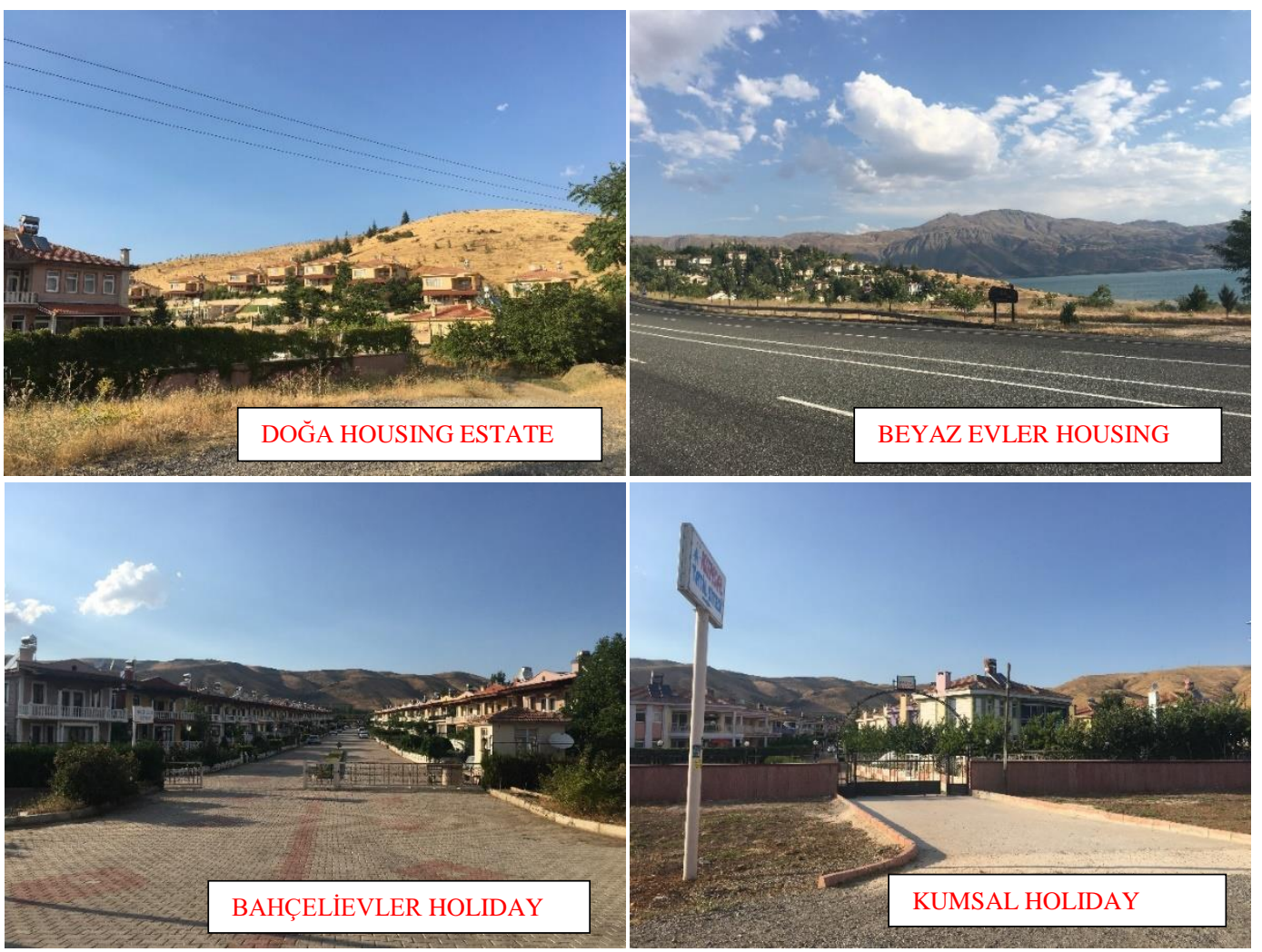

Figure 5. Housing Estates on the Elazı̆̆-Diyarbakır Highway Roadside in the Güney Village

According to the field studies carried out in the Güney village and the Multi Criteria Decision Making method, the location of the summer houses generally had the suitable conditions (Figure 3). This area is generally on the Yüksekova Complex consisting of andesite, basalt and gabbro. Therefore, even though this area is located within the earthquake zone, it has a solid feature in terms of soil mechanics and the summer houses were built probably in the most adequate place in terms of soil if they were not built on the stream bed. With this present situation, we can even say that the vicinity of Güney village is the most adequate place in terms of the soil around the coasts of Lake Hazar. Even though the Güney village was generally adequate for the construction of summer houses, as a result of the field observations, it was observed that the people built summer houses individually or as housing estates.

There is a risk of floods and overflow in summer houses built especially on the edge of dry river beds and in the valley (Figure 6). Since these coastlines also have large and long beaches, the houses, camps that belong to the state institutions and organizations, and commercial enterprises were also concentrated in this area (Figure 7). 
Geographical Analysis of Summer Houses by the Lake Hazar in Terms of their Location of Construction (Province of Elaziğ-Turkey)

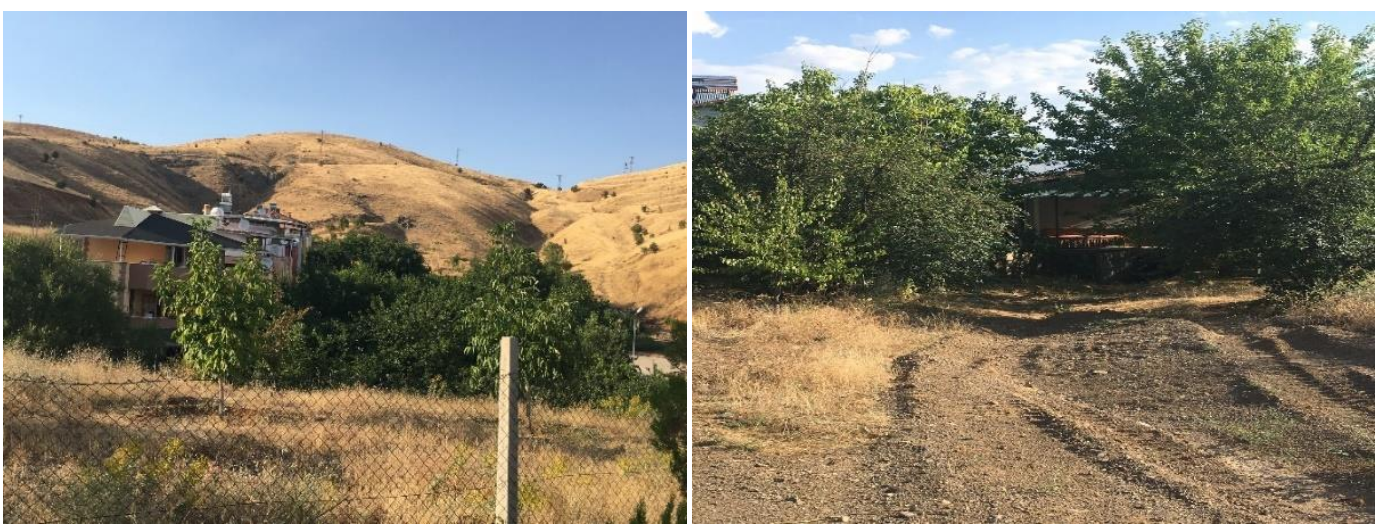

Figure 6. Inadequate for settlement a) Çiçekçioğlu Holiday estate within the valley b) Yakup Bey's House built on the Stream Bed
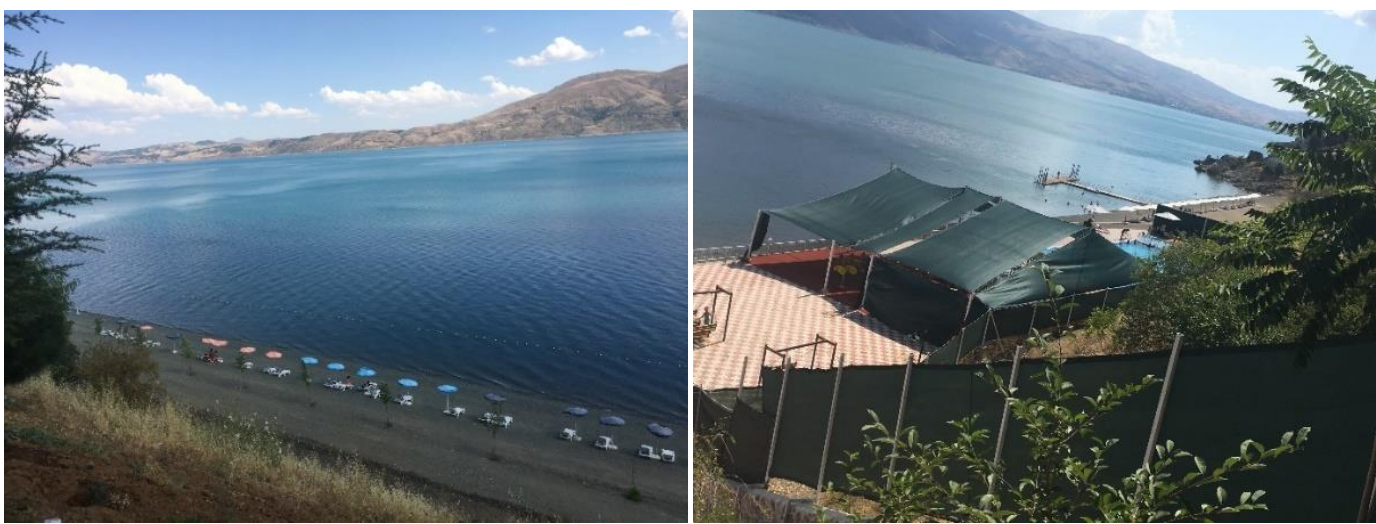

Figure 7. A View of a private resort and beaches of SHW located on the extensive north coastline of Lake Hazar

\section{Gölardı-Cevizdere Summer House Locations}

There is an area that administratively belongs to the Cevizdere and Gölardı villages on the southern outskirts of Mastar Mountain. Summer houses and housing estates were built in the neighborhoods of these villages near the coastline of Lake Hazar. These houses were generally constructed at the adequate places sloping hillsides away from the lake coast. In a way, the inhabitants of the housing estate had a bird's eye view the Lake Hazar. There are two housing estate locations with two different densities on the coastline. In these areas, there are a total of 13 housing estates with 8 houses in the area between Frrat University and Highways Training Facilities, 5 houses up to the border of Gezin village and Highways Directorate facility and 200 residences.

According to the multi-criteria decision making method and the field studies carried out in these villages, the summer houses generally had the suitable conditions for their establishment (Figure 4). The Lower Eocene aged Simaki formation consisting of sandstone, mudstone, limestone and shale is observed in this area. This area which has medium strength in terms of soil mechanics is adequate or moderately adequate for summer houses. However, considering the risk of earthquake, attention should be paid to the foundation of the houses. Moreover, due to the high degree sloping and narrow coastline, there are no dense summer residential areas as in the Güney village (Figure 8). 


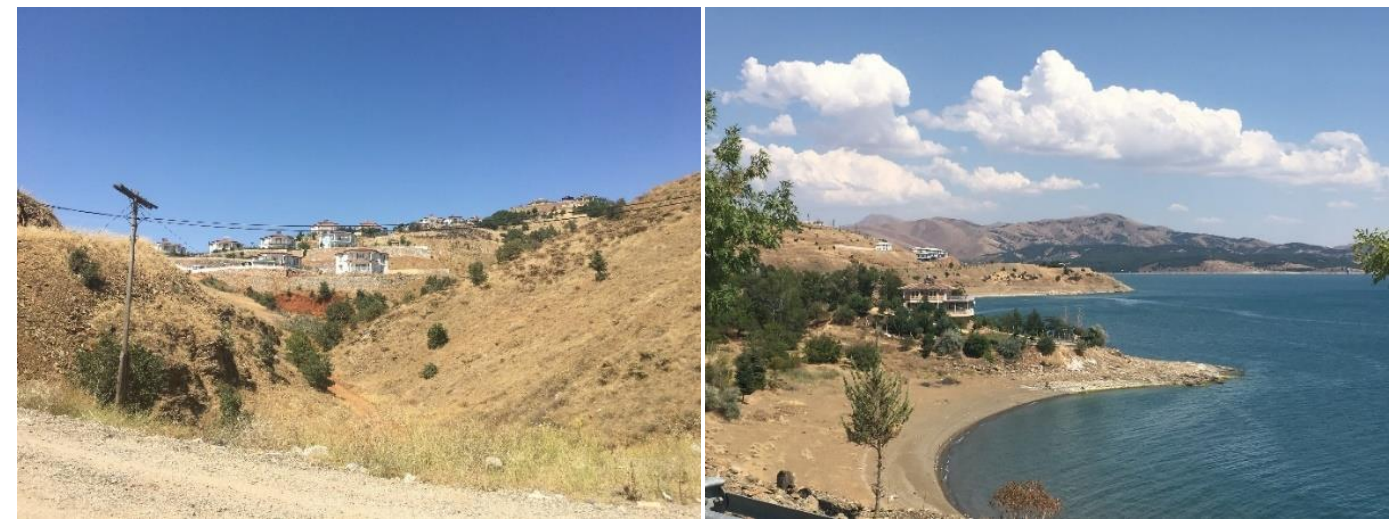

Figure 8. Summer Housing Estate in Gölardı-Cevizdere, Commercial Enterprise and Beach Areas

\section{Gezin-Plajköy Summer House Locations}

While the Gezin village affiliated with the district of Maden is located on the coast of the Lake Hazar in the east of our study area, Plajköy is located in the southeast of our study area. There are also summer residences concentrated in the villages of Gezin and Plajköy, located within the boundary of Maden district. There are 20 housing estates and 2000 homes in the village of Gezin, and 500 of these homes are used as summer houses. The winter population of Gezin is 1147 people (2017), and it reaches 20 ooo in the summer season especially by an increase at the weekends; the highest number of this increase is composed of people coming from the province of Diyarbakır. The fact that it is located in the furthest east part of the lake and the temperature conditions are compatible with that of Diyarbakir increases the attractiveness of Gezin in the summer season.

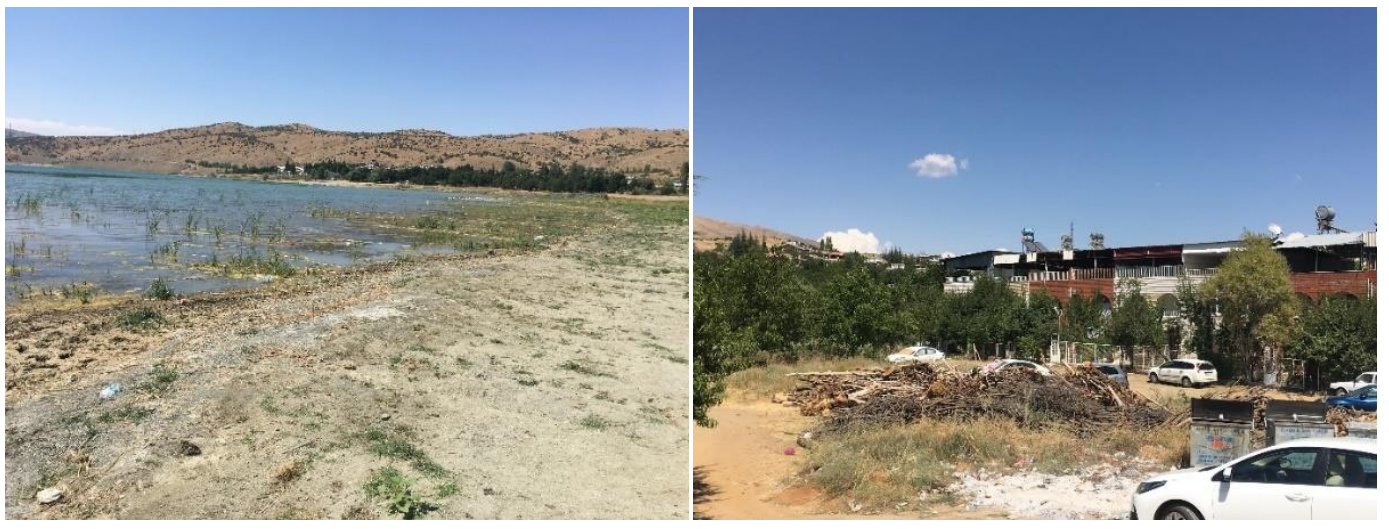

Figure 9. Visual Pollution around the Gezin Village Beach

While it formerly had the status of town municipality, but due to the amount of population, it receded back to the village status, the Gezin village started to have some problems related to service delivery and reception in the summer season. Solid waste, sewage, irregular and unplanned housing, infrastructure problems, lake pollution and the disuse of the lake for the purpose of beach together with visual pollution all have adverse effect on tourism. Since tourism planning is not done, tourism activities are carried out only with the crowd (Figure 9). The Gezin delta, which consists of alluviums 
carried by the Zıkkım stream, is adequate for the establishment of touristic facilities in terms of both geomorphological and other physical geographic factors (beach, cafeteria, camp site, etc.). According to the land adequacy map, which is generally formed by considering the geographical criteria, Gezin Village is adequate except for the delta area for the construction of summer houses-housing estates (Figure 4). The housing estates in Gezin located on the east coastline of the lake, which is situated in a tectonic basin, were generally built on the slopes because the flat areas were restricted (Figure 10). Since the delta area is an alluvium, it is not solid and is not very adequate for the construction of houses. As in the Güney village, even though the land adequacy map in the Gezin Village as well is considered adequate for summer houses, there are summer houses within the narrow valley where there is a risk of floods (Figure 11).
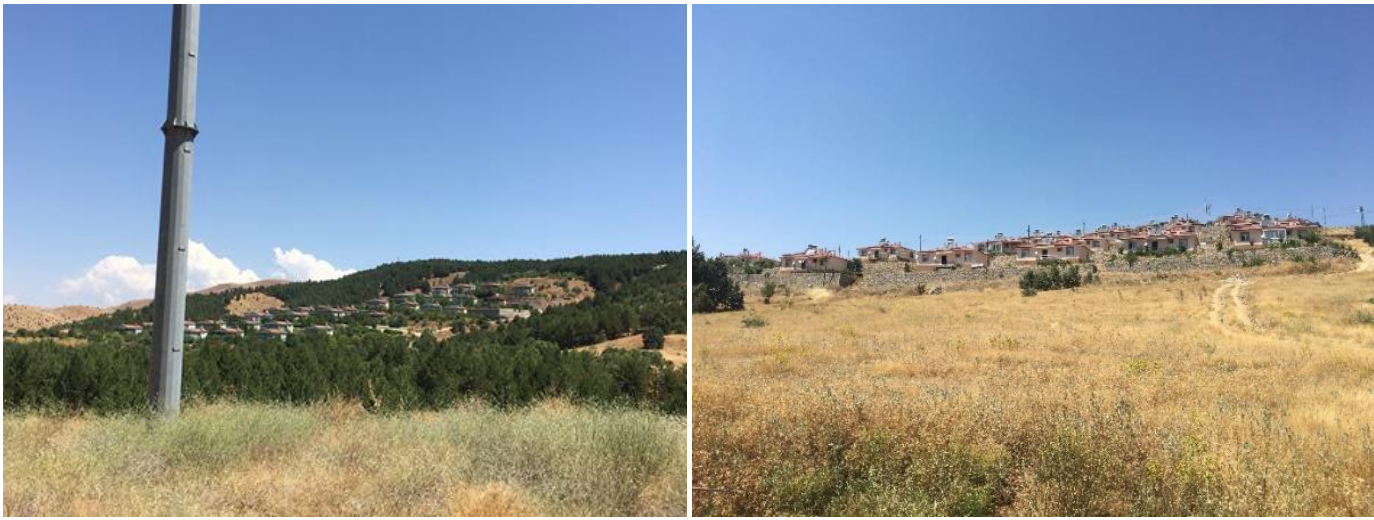

Figure 10. Summer Houses around Gezin, Especially on the Slopes of Güney Village
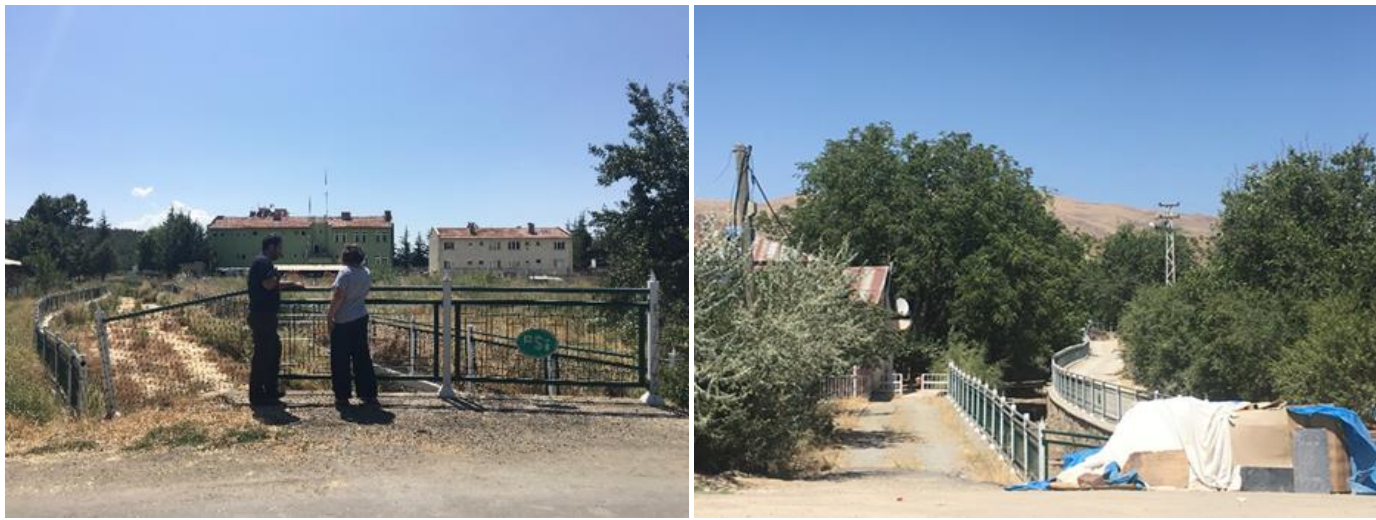

Figure 11. Houses Unsuitably Built on the River Bed in the Gezin Village

Plajköy, located in the southeast of Lake Hazar, has 14 housing estates and around 400 houses. Apart from the housing estates and houses, there are also variable number of tents and containers on the coastline (100 units). While the winter population of Plajköy is 82 (2017), it, as it is the case in Gezin, increases to 5 ooo people during the weekdays and 8000 people at the weekends. The coastlines of Plajköy a re the longest beach of Lake Hazar $(7 \mathrm{~km})$. With this characteristic, the first public institution camp site on the lake was established here (Etibank). 
At the same time, since Plajköy also has camping sites and convenient beach areas, the camping site, which was established under the name of "Kamp 21" in the 1980s, expanded and became a holiday resort (Figure 12). Even if the Plajköy beach is long, it is not adequate for the expansion of the residential areas since the village settlement is morphologically inclined and located in a high place. Therefore, the number of tents and containers on the coast camps is high (Figure 13). The Lower Eocene aged Simaki formation, consisting of sandstone, mudstone, limestone and shale, is observed in this area as well. Since the beach is established on DAF, this formation, which is earthquake-sensitive, is risky in terms of the soil. The constructed housing estates are currently at risk since they were built on unstable foundations without considering the earthquake. Furthermore, according to the adequacy analysis performed, the area around Plajköy is inadequate and less adequate for accommodation building.

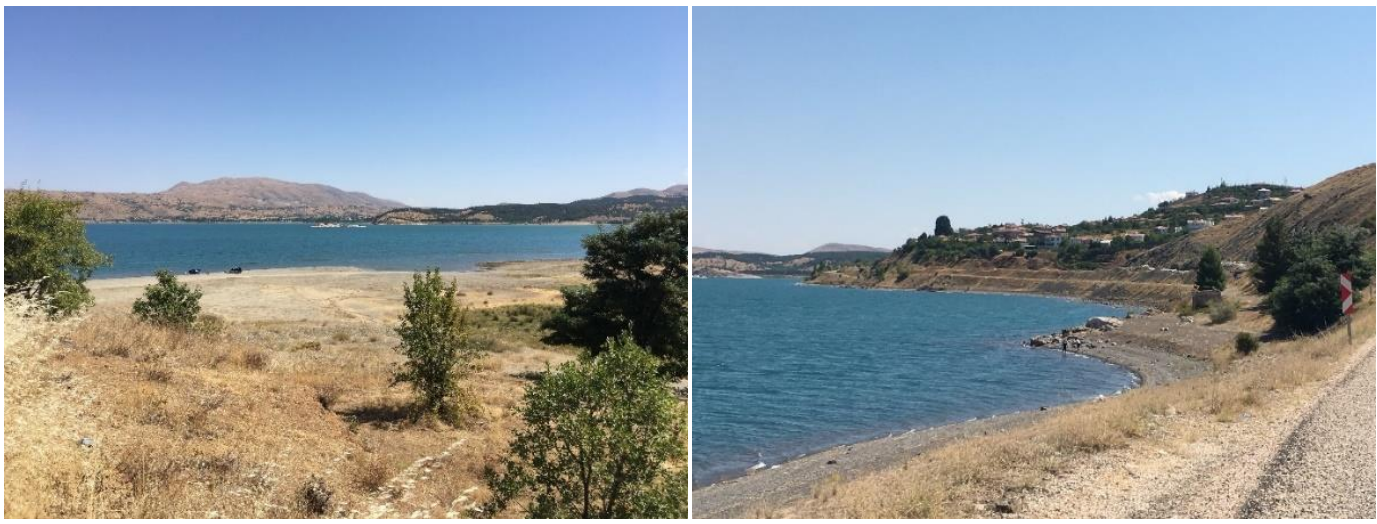

Figure 12. Length of Coastline in Plajköy and a Housing Estate on the Coast
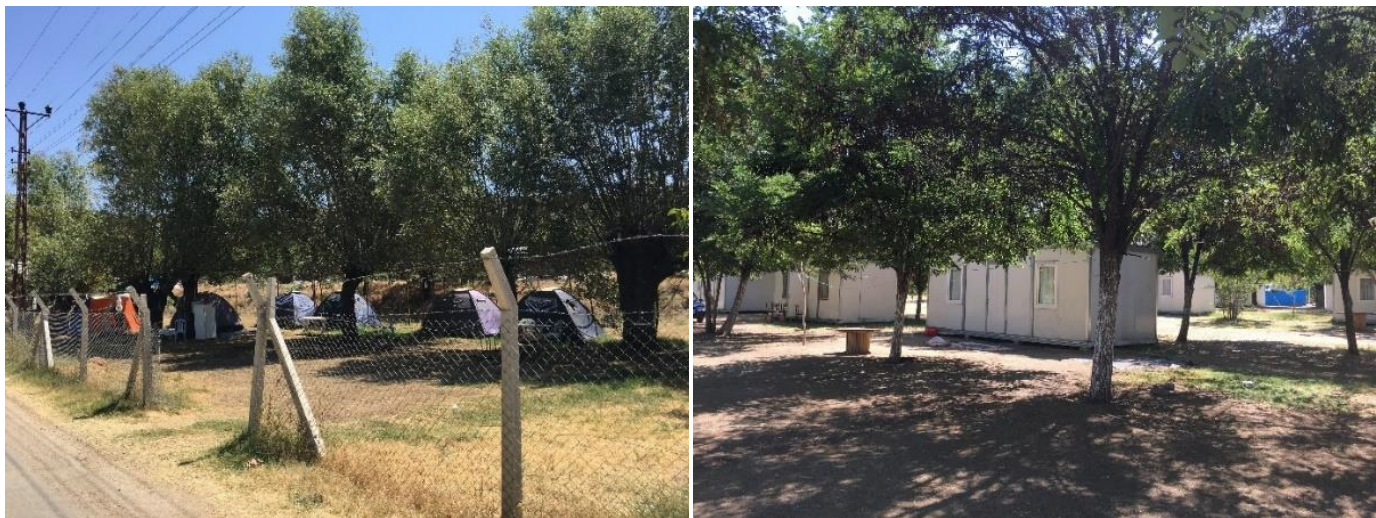

Figure 13. Images of Summer Houses, Containers and Tents in Plajköy

\section{South Coastline of Lake Hazar}

While the summer houses in the present study area were concentrated in the north-east-southeast parts of the lake, the southern coasts of the lake corresponded to the areas with the lowest density in summer houses. Since the slope and elevation in the southern coasts of the lake along the faulted steep slope of the Hazarbaba Mountains was high, the depth of the lake from the coast increased unexpectedly, that the 
transportation network was not very busy and almost non-existent and the beach areas had confined space prevented the development of summer houses (Figure 14).

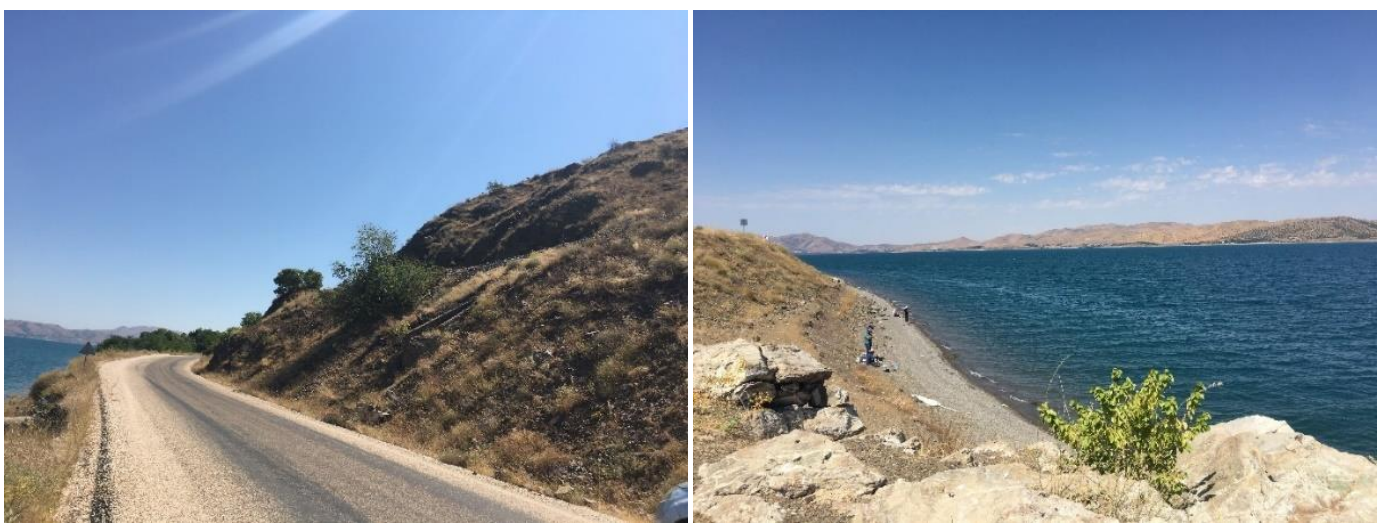

Figure 14. The Steepness of the Coastline on the South Coast

In this area, on the coasts close to Sivrice district center, there are mostly the one-day picnic and recreation areas, and camping areas which belonged to some public institutions in the past, but later were privatized and are in use today commercially.

There is also a summer community site on the conglomerate cones formed by small streams in this narrow shore and a neighborhood settlement that belongs to the Sürek village (Figure 15). The southern coasts of the lake are not geomorphologically adequate for summer houses. The results of both the field observations and the geographic criteria that we have used, as can be seen on our map, the northern skirts of the Hazarbaba Mountain are risky areas and not adequate for the development of summer houses due to both geological factors and soil mechanics and the fact that they are located within the DAF Zone (Figure 1 and 4).
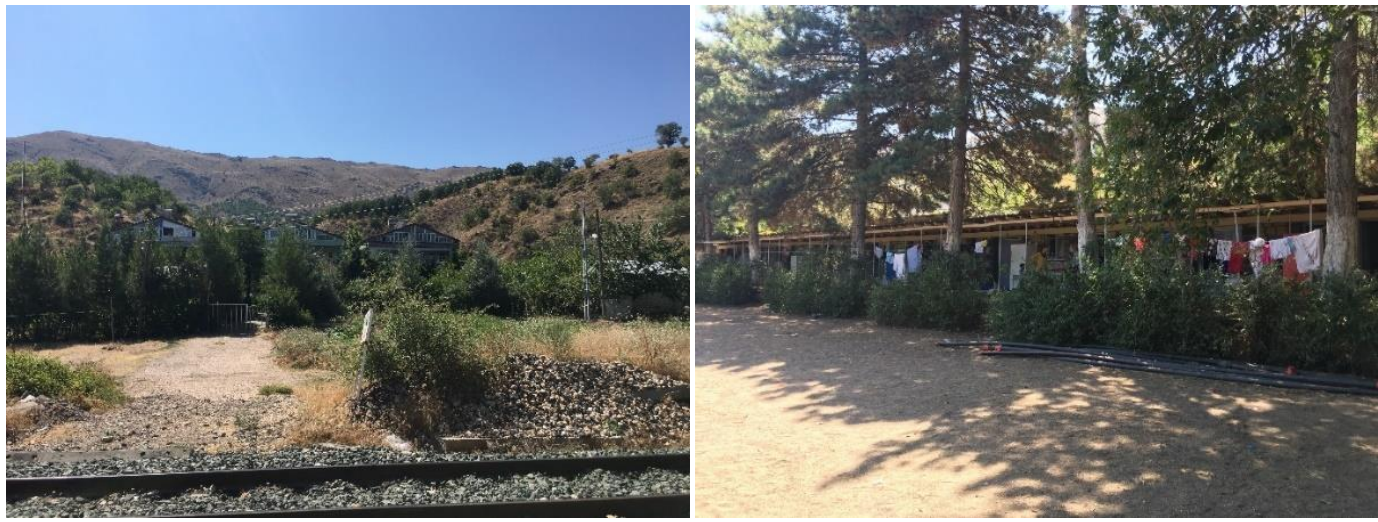

Figure 15. Yeșil Çınar community site located and Former

Facilities of State Railways on the south coast of Lake Hazar

\section{CONCLUSION}

The maps obtained in the ArcGIS program and the maps converted to the same pixel size and transformed into the raster format were subjected to "Weighted Overlay" 
analysis, and were classified as not suitable, less suitable, moderately suitable and suitable land use for summer houses. In order to access the information regarding where the houses were built, whether they were suitable for the location, the analysis map was evaluated together with the field observations and the results were obtained. The following results were obtained in this study which attempted to make a synthesis by discussing the problems of and solution suggestions to the location of the houses / holiday sites located on the shores of the Lake Hazar and the solutions of the solutions.

The first place where summer houses are densely located around Lake Hazar is on north coast of the lake, the second is on the east and southeast coasts of the lake. These areas administratively correspond to the villages of Central, Sivrice and Maden districts. The summer houses were concentrated in the villages of Güney affiliated with the Sivrice district, of Gölardı and Maden affiliated with the Central district, and of Gezin and Plajköy affiliated with the Maden district. The northern shores of the lake, which is the route that the Elazığ-Diyarbakır highway rides, are the most adequate places for the development of summer houses considering the lithology, slope and elevation factors. This area is also the place where commercial facilities (Turpol and Mavigöl) and training and recreation facilities of public institutions and organizations are concentrated. The fact that there exist the state and private businesses on the coasts with wide beaches restricts the use of the lake by the summer house vacationist and daily visitors.

Administratively, since the lake is located in three different districts (Merkez, Sivrice and Maden), there is no common view about the lake in terms of tourism planning. Furthermore, since the services are provided in different ways by the Special Provincial Administration and the Municipality of Sivrice, there has been disharmony in the provision of services. In order to prevent this chaos, an urgent planning should be made for the coastlines of the Lake Hazar and the management should be made singular.

In this study in which we analyzed the adequacy of the summer houses around the Lake Hazar in terms of their location, clearly there is a similarity between the result map and the present-day outlook. When we look at the adequacy map, the northern shores of the lake are more adequate for the settlement and second housing development than the southern shores. The lack of faulted steep slopes and the high accumulation of conglomerate cones enabled the creation of spread-out coasts and beaches, and made the northern coasts advantageous in terms of transportation and settlement, unlike the southern coasts of the lake. Housing started with the second residential-summer community houses on the coastlines of the naturally existing village settlements. This is because these areas are both advantageous and adequate in terms of soil together with the presence of transportation network. Even though the northern parts of the lake seem to be adequate for development, some of the summer community sites are located along the creek and within the creek. Although these areas are dry streams, they were subject to floods in the past and therefore are not adequate for residential areas. Around Lake Hazar, it is observed that summer houses were, in general, built in adequate places, apart from the exceptional cases according to the adequacy map and field observations made with the help of GIS.

\section{REFERENCES}

Adamiak, C., Vepsäläinen, M., \& Strandell, A. (2015). Second Home Tourism in Finland, Perception of Citizens and Municipalities on the State and Development of Second Homes Tourism. Reports of Finnish Environment Institute, https://helda.helsinki. fi/handle/10138/155090. Accessed on January 20, 2017. 
Arkon, C. (1997). 'Kıyılarımızın günümüzdeki görüntüsü’ Ege Mimarlı, Yıl: 7, 24, 39-43 İzmir. (Accessed on January 20, 2017. Arkon, C. (1997). 'View of our Coasts Today' Ege Architecture, Year: 7, 24, 39-43 İzmir).

Dağlı, D., \& Çağlıyan, A. (2016). Analitik Hiyerarşi Süreci İle Optimal Arazi Kullaniminin Belirlenmesi: Melendiz Çayi Havzasi Örneği. Türk Coğrafya Dergisi, (66), 83-92, https://doi.org/10.17211/tcd.28071 (Determination of Optimal Land Use by Analytical Hierarchy Process: The Case of Melendiz River Basin. Turkish Journal of Geography, (66), 83-92, https://doi.org/10.17211/tcd.28071).

Emekli, G. (2014). İkinci Konut Kavramı Açısından Turizm Coğrafyasının Önemi ve Türkiye'de İkinci Konutların Gelişimi, Ege Coğrafya Dergisi, 23/1(2014), 25-42, İzmir. (Importance of Tourism Geography in terms of Second Housing Concept and Development of Second Homes in Turkey, Aegean Geographical Journal, 23/1 (2014), 25-42, Izmir).

Hall, C.M. \& Müller, D.K. (2004) (Ed.). Tourism, Mobility and Second Homes: Between Elite Landscapes and Common Ground. Channel View Publications.

Hiltunen, M.J. (2007). Environmental Impacts of Rural Second Home Tourism - Case Lake District in Finland. Scandinavian Journal of Hospitality and Tourism, 7(3), 243-265.

Hoogendoorn, G. \& Visser, G. (2010). The Economic Impact of Second Home Development in Small-Town South Africa. Tourism Recreation Research, 35(1), 55- 66.

Kabıyev, Y.S., Berdenov, Z.G., Dzhanaleeva, K.M., Atasoy, E. \& Wendt J.A. (2018). Landscape Ecological Analysıs Of The Modern, Delta Of The Ural (Zhayı) River, GeoJournal of Tourism and Geosites Year XI, vol. 23, no. 3, p.644-655 ISSN 2065-0817, E-ISSN 2065-1198.

Kozak, M. \& Duman, T. (2011). İkinci Konutların Turizm Sektörüne Kazandırılması: Muğla İli Datça İlçesi Örneği, Doğuş Üniversitesi Dergisi, 12 (2) 2011, 226-242 (Acquisition of Second Housing to the Tourism Sector: Case of Datça District of the Muğla Province, Doğuş University Journal, 12 (2) 2011, 226-242.

Küçük H. (2016). Karasu İlçesi’nde (Sakarya) İkincil Konutlarin Gelişimi, Bilecik Şeyh Edebali Üniversitesi Sosyal Bilimler Enstitüsü Coğrafya Anabilim Dali, Basılmamış Yüksek Lisans Tezi, Bilecik. (Development of Secondary Houses in the Karasu District (Sakarya), Institute of Social Sciences Department of Geography, Bilecik Şeyh Edebali University, Unpublished Master's Thesis, Bilecik).

Long, D. \& Hoogendoorn, G. (2013). Second Home Owner Percepsitons of Their Environmental Impacts: The Case of Hartbeespoort. Urban Forum, 25, 517-530.

Marjavaara, R. (2008). Second Home Tourism: the Root to Displacement in Sweden? Yayınlanmamış Doktora Tezi (Unpublished Ph.D. Thesis), Umea University, Faculty of Social Sciences, Department of Social and Economic Geography, Sweden.

Muller, D. K. (2004). Mobility, Tourism, and Second Homes. InLew, A. A., Hall, C. M. and Williams, A.M. (Eds) A Companion to Tourism. Oxford. Blackwell: 387-398.

Özgüç, N. (1977). Tatil evleri. İ.T.̈̈. Mimarlk Fakültesi Şehircilik Enstitüsü Dergisi 14, 69-92, İstanbul. (Holiday homes. İ.T.Ü. Faculty of Architecture, Journal of Institute of Urbanism 14, 69-92, Istanbul).

Richards, G. (2017). Sharing the New Localities of Tourism. Cited in; Dianne Dredge \& Szilvia Gyimóthy (Editors) Collaborative Economy and Tourism: Perspectives, Politics and Prospects (ss. 169-184) Springer.

Rogerson, J. M., (2018). The Geography of Tourıst Bed nights in South Africa, Geojournal of Tourism and Geosites Year Xl, Vol. 23, No. 3, 2018, P.835-847 Issn. 2065-0817, E-Issn. 2065-1198.

Roca, Z. (2013). (Ed.) Second Home Tourism in Europe: Lifestyle Issues and Policy Responses. Farnham: Ashgate Publishing.

Roca, M.N., Roca, Z. \& Oliveira, J.A., (2011). Features and Impacts of Second Home Expansion: the Case of the Oeste Region Portugal. Hrvatski Geografski Glasnik, 73(2), 111-128.

Rye, J.F. (2011). Conflicts and contestations. Rural populations' perspectives on the second homes phenomenon. Journal of Rural Studies, 27, 263-274.

Yiğit, A. (1994). Sivrice-Maden Yöresinin Mevzii Coğrafyası, Fırat Üniversitesi, Sosyal Bilimler Enstitüsü (Yayınlanmamış Doktora Tezi), Elazı̆̆. (Geography of Sivrice-Maden Region, Institute of Social Sciences, Firat University (Unpublished Ph.D. Thesis), Elazığ).

Submitted:

07.03.2019
Revised:

09.07.2019
Accepted and published online 30.07.2019 